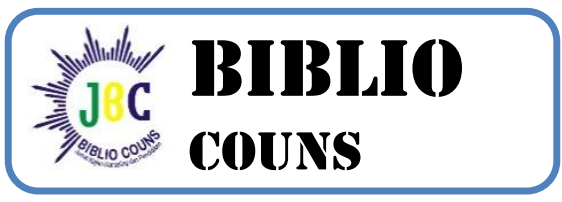

\title{
PENGARUH SELF-EFFICACY DAN COPING TERHADAP PERILAKU ASSERTIF MAHASISWA
}

\section{Sri Ngayomi Yudha Wastuti, Feri Haryati}

University Muhammadiyah Sumatera Utara, Medan, Sumatera Utara, Indonesia. Korespondensi: Jl. Muchtar Basri No. 3 Medan. Email: sringayomi@umsu.ac.id , feriharyati@umsu.ac.id

\section{Article Info}

History of Article

Submited Maret 2019

Accepted Maret 2019

Published Maret 2019

\section{Key Word}

Self-Efficacy,

Coping,

Assertive Behavior

\section{Kata Kunci}

Efikasi Diri

Coping

Perilaku Asertif

\begin{abstract}
This research is based on the assumption that there is a relationship between self-efficacy and coping on student behavior. This study uses a correlational quantitative type approach. The population in this study was 142 people, and samples were taken using Simple Random Sampling of 60 people. The data analysis technique uses product moment correlation and multiple linear regression. The results showed that the variables of self-efficacy and coping had a joint effect on student behavior.
\end{abstract}

\begin{abstract}
Abstrak
Penelitian ini berdasarkan asumsi bahwa terdapat hubungan antara self-efficacy dan coping terhadap perilaku mahasiswa. Penelitian ini menggunakan pendekatan Kuantitatif jenis korelasional. Populasi dalam penelitian ini yaitu 142 orang, serta sampel diambil dengan teknik Simple Random Sampling sejumlah 60 orang. Teknik analisis data menggunakan korelasi product moment dan Regresi Linear Berganda. Hasil penelitian menunjukkan bahwa variabel self-efficacy dan coping berpengaruh secara Bersama-sama terhadap perilaku mahasiswa.
\end{abstract}

\section{Citation Info}

Wastuti, S.N.Y., dan Haryati, F., (2019). Pengaruh Self-Efficacy dan Coping Terhadap Perilaku Assertif Mahasiswa. In Biblio Couns: Jurnal Kajian Konseling dan Pendidikan, 2(01), 54-60. 


\section{PENDAHULUAN}

Kesiapan mahasiswa untuk menjalankan tugasnya ini ditunjukan dengan perilaku yang dapat diterima oleh lingkungan yang menunjukan kompetensi dirinya, mampu menghargai kepentingan orang lain, dapat mengekspresikan diri secara penuh, menggunakan hak pribadi tetapi tidak mengabaikan hak orang lain. Perilaku inilah yang disebut sebagai perilaku asertif, sebagaimana pendapat Lloyd (dalam Novalia dan Dayakisni, 2013) perilaku asertif adalah perilaku bersifat aktif, langsung, dan jujur. Perilaku ini mampu mengkomunikasikan kesan respek kepada diri sendiri dan orang lain sehingga dapat memandang keinginan, kebutuhan, dan hak kita sama dengan keinginan, dan kebutuhan orang lain atau bisa diartikan juga sebagai gaya wajar yang tidak lebih dari sikap langsung, jujur, dan penuh respek saat berinteraksi dengan orang lain. Perilaku asertif inilah yang diharapkan mampu mendukung mahasiswa melaksanakan layanan bimbingan dan konseling di sekolah.

Keberanian dalam memberikan layanan di kelas membutuhkan dorongan yang kuat untuk menggerakan individu mengeluarkan kemampuan yang dimilikinya. Dorongan ini dapat diperoleh ketika individu yakin bahwa dirinya memiliki kemampuan. Dalam hal ini individu harus memiliki penilaian yang baik akan potensi yang dimilikinya atau dikatakan sebagai self-efficacy, sebagaimana pendapat Bandura (1986) dalam Baron dan Byrne (2005) mengemukakan bahwa self-efficacy merupakan penilaian individu terhadap kemampuan atau kompetensinya untuk melakukan suatu tugas, mencapai suatu tujuan, dan menghasilkan sesuatu.

Disamping self-efficacy, permasalahan yang terkait dengan kemampuan untuk memberikan layanan bimbingan dan konseling adalah bagaimana individu mampu menyelesaikan kesulitannya dengan cara-cara yang efektif yang disebut sebagai Coping. Perilaku mengatasi masalah (coping) menurut Lazarus dan Folkmana (1984) dalam Mayudia (2011) adalah suatu tindakan merubah kognitif secara konstan dan merupakan suatu usaha tingkah laku untuk mengatasi tuntutan internal atau eksternal yang dinilai membebani atau melebihi sumber daya yang dimiliki oleh individu. Coping dipandang sebagai suatu usaha untuk mengatasi situasi tertekan tanpa memperhatikan akibat dari tekanan tersebut, tetapi coping bukan merupakan suatu usaha untuk menguasai seluruh situasi yang menekan karena tidak semua situasi tersebut dapat benar-benar dikuasai. Kondisi ini memungkinkan seseorang dapat melakukan coping yang efektif, yaitu coping yang membantu seseorang untuk mentoleransi dan menerima situasi menekan dan tidak merisaukan tekanan yang tidak dapat dikuasainya (Lazarus \& Folkman, 1984) dalam Siswanto (2007).

Sebagai calon konselor di sekolah, mahasiswa bimbingan dan konseling dituntut untuk mampu secara mandiri dan professional melaksanakan layanan bimbingan dan konseling namun tidak selancar yang diharapkan. Berdasarkan paparan diatas peneliti tertarik untuk meneliti "Pengaruh Self-efficacy dan coping terhadap Perilaku Assertif Mahasiswa Prodi Bimbingan dan Koseling Fakultas Keguruan dan IImu Pendidikan Universitas Muhammadiyah Sumatera Utara Tahun Ajaran 2017-2018". 


\section{METODOLOGI PENELITIAN}

Secara umum penelitian ini bertujuan untuk memperoleh gambaran yang objektif mengenai pengaruh self-efficacy dan coping terhadap perilaku assertif Mahasiswa Bimbingan dan Konseling FKIP Universitas Muhammadiyah Sumatera Utara. Penelitian ini merupakan penelitian kuantitatif dengan metode penelitian non eksperimen. Penelitian ini ditujukan untuk mengetahui tingkat signifikan pengaruh variabel $\mathrm{X}_{1}$ (Self Efficacy) dan $\mathrm{X}_{2}$ (Coping) terhadap variabel $\mathrm{Y}$ (Perilaku Asertif) pada mahasiswa yang diperoleh melalui pengisian kuesioner secara tertulis, yang kemudian hasilnya dianalisis menggunakan metoda statistik Regresi Linier dengan 3 prediktor dengan bantuan aplikasi SPSS.19. Instrumen yang digunakan dalam penelitian ini adalah skala yang bersifat tertutup, yaitu pertanyaan yang dibuat sedemikian rupa hingga responden dibatasi dalam memberi jawaban kepada beberapa alternatif saja atau kepada satu jawaban saja (Nasir, 1988). Skala pada penelitian ini menggunakan Skala pengukuran self efficacy (efikasi diri), skala pengukuran coping,dan skala pengukuran perilaku asertif. Instrumen yang digunakan telah diuji Validitas dan Reliabilitasnya dengan hasil uji instrument valid dan reliabel.

\section{HASIL PENELITIAN}

\section{Pengaruh Self Efficacy Terhadap Perilaku Asertif Mahasiswa}

Untuk mengetahui ada tidaknya pengaruh pengaruh Self Efficacy $\left(X_{1}\right)$ terhadap perilaku asertif $(Y$ ) digunakan regresi sederhana dan dapat diketahui seperti tabel berikut ini :

Tabel 1. Hasil Uji Korelasi $X_{1}$ terhadap $Y$

\begin{tabular}{cccc}
\hline Model & R & R Square & Adjusted R Square \\
\hline 1 & $.980^{\mathrm{a}}$ & .960 & .959 \\
\hline
\end{tabular}

Berdasarkan Tabel di atas, diketahui adanya hubungan positif antara Self efficacy $\left(X_{1}\right)$ dengan perilaku asertif $(Y)$ yang ditunjukan oleh besarnya koefisien korelasi $(r)$ yaitu $r_{\text {hitung }}=0.980$. Berdasarkan tabel interpretasi nilai $r$, hubungan variabel self efficacy $\left(\mathrm{X}_{1}\right)$ terhadap variabel perilaku asertif $(\mathrm{Y})$ adalah positif dan sangat kuat.

\section{Tabel 2. Uji Hipotesis $X_{1}$ terhadap $Y$}

\begin{tabular}{ccccccc}
\hline \multirow{2}{*}{$\mathbf{J}$} & \multicolumn{2}{c}{$\begin{array}{c}\text { Unstandardized } \\
\text { Coefficients }\end{array}$} & $\begin{array}{c}\text { Standardized } \\
\text { Coefficients }\end{array}$ & \multirow{2}{*}{$\mathbf{t}$} & Sig. \\
\cline { 2 - 5 } & $\mathrm{B}$ & Std. Error & Beta & & \\
\hline \multirow{2}{*}{1} & (Constant) & -9.276 & 2.783 & & -3.333 & .001 \\
\cline { 2 - 5 } & SelfEfficacy & .908 & .024 & .980 & 37.221 & .000 \\
\hline
\end{tabular}


Berdasarkan tabel di atas dapat dilihat bahwa nilai $t$ hitung $=37,221$, sedangkan dengan $\alpha=0,05$ uji dua pihak (two tail test) dan $\mathrm{dk}=60-2=58$, maka diperoleh $t$ tabel $=2,002$. Dengan demikian $t$ hitung $>t$ tabel $(37,221>2,002)$ yang artinya tolak Ho dan terima Ha. Jadi dapat disimpulkan bahwa, hipotesis yang menyatakan ada pengaruh variabel self efficacy $\left(\mathrm{X}_{1}\right)$ terhadap variabel perilaku asertif $(\mathrm{Y})$ telah teruji.

\section{Pengaruh Coping Terhadap Perilaku Asertif Mahasiswa}

Untuk mengetahui ada tidaknya pengaruh pengaruh Coping $\left(\mathrm{X}_{1}\right)$ terhadap perilaku asertif ( $Y$ ) digunakan regresi sederhana dan dapat diketahui seperti tabel berikut ini :

Tabel 3. Hasil Uji Korelasi $\mathrm{X}_{2}$ terhadap $\mathrm{Y}$

\begin{tabular}{cccc}
\hline Model & R & R Square & Adjusted R Square \\
\hline $\mathbf{1}$ & $.975^{\mathrm{a}}$ & .950 & .949 \\
\hline
\end{tabular}

Berdasarkan tabel di atas, diketahui adanya hubungan positif antara coping $\left(\mathrm{X}_{2}\right)$ dengan perilaku asertif $(\mathrm{Y})$ yang ditunjukan oleh besarnya koefisien korelasi $(\mathrm{r}$ ) yaitu ritung $=0.975$. Berdasarkan tabel interpretasi nilai $r$, hubungan variabel Coping $\left(\mathrm{X}_{2}\right)$ terhadap variabel perilaku asertif $(\mathrm{Y})$ adalah positif dan sangat kuat.

Tabel 4. Uji Hipotesis $X_{2}$ terhadap $Y$

\begin{tabular}{cccccccc}
\hline \multirow{2}{*}{$\mathbf{J}$} & \multicolumn{2}{c}{$\begin{array}{c}\text { Unstandardized } \\
\text { Coefficients }\end{array}$} & \multicolumn{2}{c}{$\begin{array}{c}\text { Standardized } \\
\text { Coefficients }\end{array}$} & \multirow{2}{*}{ t } & Sig. \\
\cline { 3 - 5 } & & B & Std. Error & Beta & & \\
\hline \multirow{2}{*}{$\mathbf{1}$} & (Constant) & -12.643 & 3.220 & & -3.926 & .000 \\
\cline { 2 - 5 } & Coping & .851 & .026 & .975 & 33.207 & .000 \\
\hline
\end{tabular}

Berdasarkan tabel di atas dapat dilihat bahwa nilai $t$ hitung $=33,207$, sedangkan dengan $\alpha=0,05$ uji dua pihak (two tail test) dan $\mathrm{dk}=60-2=58$, maka diperoleh $t_{\text {tabel }}=2,002$. Dengan demikian $t$ hitung $>t$ tabel $(33,207>2,002)$ yang artinya tolak Ho dan terima $\mathrm{Ha}$. Jadi dapat disimpulkan bahwa, hipotesis yang menyatakan ada pengaruh variabel Coping $\left(\mathrm{X}_{2}\right)$ terhadap variabel perilaku asertif $(\mathrm{Y})$ telah teruji.

\section{Pengaruh Self Efficacy dan Coping Terhadap Perilaku Asertif Mahasiswa}

Untuk mengetahui ada tidaknya pengaruh pengaruh self efficacy $\left(X_{1}\right)$ dan Coping $\left(\mathrm{X}_{2}\right)$ terhadap perilaku asertif $(\mathrm{Y})$ digunakan regresi linear berganda dan dapat diketahui seperti tabel berikut ini :

Tabel 5. Hasil Uji Korelasi $X_{1}$ dan $X_{2}$ terhadap $Y$

\begin{tabular}{cccc}
\hline Model & R & R Square & $\begin{array}{c}\text { Adjusted R Square } \\
\end{array}$ \\
\hline 1 & $.981^{\mathrm{a}}$ & .963 & .962 \\
\hline
\end{tabular}


Berdasarkan tabel di atas, diketahui adanya hubungan positif antara Self efficacy $\left(X_{1}\right)$, Coping $\left(X_{2}\right)$ dengan perilaku asertif $(Y)$ yang ditunjukan oleh besarnya koefisien korelasi $(r)$ yaitu $r_{\text {hitung }}=0.981$. Berdasarkan tabel interpretasi nilai $r$, hubungan variabel self efficacy $\left(\mathrm{X}_{1}\right)$ dan variabel Coping $\left(\mathrm{X}_{2}\right)$ secara bersama-sama terhadap variabel Perilaku Asertif $(\mathrm{Y})$ adalah positif dan sangat kuat.

Tabel 6. Uji Hipotesis $X_{1}$ dan $X_{2}$ terhadap $Y$

\begin{tabular}{cccccccc}
\hline \multirow{2}{*}{ Model } & \multicolumn{2}{c}{$\begin{array}{c}\text { Unstandardized } \\
\text { Coefficients }\end{array}$} & \multicolumn{2}{c}{$\begin{array}{c}\text { Standardized } \\
\text { Coefficients }\end{array}$} & t & & Sig. \\
\cline { 3 - 6 } & & B & Std. Error & Beta & & \\
\hline \multirow{2}{*}{1} & (Constant) & -5.184 & 3.249 & & -1.596 & .116 \\
\cline { 2 - 7 } & SelfEfficacy & 1.814 & .404 & 1.958 & 4.490 & .000 \\
\hline & Coping & -.855 & .381 & -.980 & -2.247 & .029 \\
\hline
\end{tabular}

Dari tabel di atas dapat dilihat bahwa nilai $t$ hitung $=4,490$, sedangkan dengan $\alpha=0,05$ uji dua pihak (two tail test) dan $\mathrm{dk}=60-2=58$, maka diperoleh $\mathrm{t}$ tabel $=$ 2,002 . Dengan demikian $t$ hitung $>t$ tabel $(4,490>2,002)$ yang artinya tolak Ho dan terima $\mathrm{Ha}$. Jadi dapat disimpulkan bahwa, hipotesis yang menyatakan ada pengaruh variabel self efficacy $\left(\mathrm{X}_{1}\right)$ dan Coping $\left(\mathrm{X}_{2}\right)$ terhadap variabel perilaku asertif $(\mathrm{Y})$ telah teruji.

\section{PEMBAHASAN}

Dari hasil uji hipotesis penelitian di atas, terbukti bahwa " Ada pengaruh yang signifikan self efficacy dan Coping terhadap perilaku asertif mahasiswa Prodi Bimbingan dan Konseling FKIP UMSU Tahun Ajaran 2017-2018. Hal ini dibuktikan berdasarkan perhitungan melalui aplikasi SPSS.19. Berdasarkan kriteria pada tabel interpretasi nilai $r$, dimana $r=0,981$ menunjukan hubungan variabel self efficacy $\left(X_{1}\right)$ dan variabel Coping $\left(\mathrm{X}_{2}\right)$ secara bersama-sama terhadap variabel Perilaku Asertif $(\mathrm{Y})$ adalah positif dan sangat kuat.

Pengaruh variabel self efficacy $\left(\mathrm{X}_{1}\right)$ dan variabel Coping $\left(\mathrm{X}_{2}\right)$ secara bersamasama terhadap variabel perilaku asertif $(Y)$ digunakan koefisien determinasi. Hasilnya dapat dilihat pada kolom $R^{\text {Square }}\left(R^{2}\right)$ yaitu sebesar 0,963 atau 96,3\% dipengaruhi oleh variabel self efficacy $\left(X_{1}\right)$ dan variabel Coping $\left(X_{2}\right)$ Sedangkan sisanya 0,037 atau $3,7 \%$ dipengaruhi oleh faktor lain.

Variabel Sefl efficacy dan coping memiliki pengaruh yang signifikan dan memiliki kebermaknaan yang ditunjukan oleh nilai $F(743,574>3,16)$, sehingga dapat dikatakan bahwa pengaruh variabel self efficacy $\left(X_{1}\right)$ dan variabel coping $\left(X_{2}\right)$ secara bersama-sama terhadap variabel perilaku asertif $(Y)$ signifikan dan memiliki kebermaknaan.

Dengan demikian dapat dikatakan semakin mahasiswa dapat mempertahankan keyakinan dirinya akan nilai-nilai yang positip terhadap perasalahan yg dihadapinya, maka mahasiswa semakin mudah memahami permasalahan dan mencari berbagai alternatif untuk menyelesaikan masalah yang 
dia hadapi , situasi tersebut makin menumbuhkan keberanian mahasiswa untuk menyampaikan ide/hasil analisisnya secara terbuka dan dapat diterima oleh orang lain dengan baik.

\section{KESIMPULAN}

Berdasarkan hasil penelitian, maka dapat ditarik kesimpulan yaitu:

1. Self efficacy pada mahasiswa memiliki korelasi yang sangat kuat sebesar 0,980 dimana 96\% self efficacy memberikan pengaruh terhadap perilaku asertif mahasiswa Prodi BK dan 4\% lainnya dipengaruhi faktor lain.

2. Coping pada mahasiswa memiliki pengaruh yang sangat kuat sebesar 0,975 dimana 95\% coping memberikan pengaruh terhadap perilaku asertif mahasiswa prodi BK dan $5 \%$ lainnya dipengaruhi oleh factor lain.

3. Secara bersama-sama self efficacy dan coping memiliki pengaruh yang sangat kuat sebesar 0,981 dimana 96,3\% self efficacy dan coping secara bersama-sama memberikan pengaruhnya terhadap perilaku asertif mahasiswa prodi BK dan $3,7 \%$ dipengaruhi oleh factor lain.

4. Pengaruh yang sangat kuat antar variabel ini menunjukan bahwa self efficacy dan coping berpengaruh terhadap munculnya perilaku asertif sehingga dapat dikatakan bahwa semakin kuat self effikasi dan coping yang dimiliki mahasiswa maka semakin kuat kemampuan mahasiswa untuk berperilaku asertif yang memudahkan mahasiswa dalam melaksanakan layanan bimbingan dan konseling di depan kelas.

\section{REFERENSI}

Arrozy , Ichda Satria Figraha . 2012, Upaya Peningkatan Sikap Asertif Melalui Sosiodrma Pada Siswa Kelas X.1 Administrasi Perkantoran Smk Sudirman 1 Wonogiri Tahun Ajaran 2011/2012. S1 thesis, UNIVERSITAS NEGERI YOGYAKARTA.

Bandura, Alber. 1997. Self-efficacy: The Exercise of Control. New York: Freeman.

Baron, R. A. \& Byrne, D. (2005). Psikologi Sosial (edisi 10). Jakarta : Penerbit Erlangga.

Husein Umar, 2011, Metode Penelitian Untuk Skripsi Dan Tesis Bisnis, Jakarta: Raja Grafindo Persada.

MacArthur, J.D. \& MacArthur, C.T. 2009. Coping Strategies, Cambridge, Cambridge University Press.

Novalia dan Dayakisni, T. (2013). Perilaku Asertif Dan Kecenderungan Menjadi Korban Bullying. Jurnal IImiah Psikologi Terapan. 172-178. 1(01).

Sarafino, Edward P. 2006. Health Psychology Biopsychosocial interaction, New York : John Wiley \& Sons. 
Biblio Couns : Jurnal Kajian Konseling dan Pendidikan | Vol. 2 No. 1 Maret 2019

Siswanto. 2007. Kesehatan mental, konsep, cakupan dan perkembangannya, Yogyakarta: ANDI.

Sugiyono, 2008, Metode Penelitian Kuantitatif Kualitatif Dan R \& D, Bandung: Alfabeta.

Taylor, E., Shelley. (2009). Psikologi Sosial. Jakarta : Kencana Predana Media.

Tohirin, 2013, Bimbingan dan Konseling di Sekolah dan Madrasah (Berbasis Integrasi), Jakarta: Rajawali Pers. 